Original Paper http://ajol.info/index.php/ijbcs http://indexmedicus.afro.who.int

\title{
On station maggot production using poultry litter as substrate: assessment on the quantity and the chemical quality of the litter before and after maggot production in Burkina Faso
}

\author{
Kalifa COULIBALY*, Fernand SANKARA, Salimata POUSGA, \\ Philippe J. NACOULMA, Marc B. SOMÉ and Hassan B. NACRO
}

Nazi Boni University (UNB), Institute of Rural Development (IDR), 01 PO Box. 1091 Bobo-Dioulasso 01, Burkina Faso.

*Corresponding author; E-mail: kalifacoul1@yahoo.fr, Tel : +226 70293310

\begin{abstract}
The maximization of organic substrates production for land sustainable management is a major challenge for agricultural production in countries like Burkina Faso. The objective of this study was to assess the quantity and the quality of organic substrates produced by poultry activity on station. Therefore, 54 local chickens at eighteen months old were allocated to 3 batches (boxes), with 18 chickens per batch. Rice husk was spread on the floor of the 3 boxes as litter for the chickens. The chickens were reared on the litter for 6 months in semi-confinement. Then, the poultry litter (PL) was used as substrate for maggots' production. The quantities and the chemical characteristics of the raw PL as well as the residues of the litter after maggots' production (RMP) were determined, and, simulations were done to estimate the quantities of organic substrates and the chemical nutrients that poultry farms can produce. The results show a production of $226.06 \mathrm{~kg} \mathrm{DM}$ of PL after 6 months of semi- confinement, with a decrease of $30.33 \%$ when the PL was used to produce maggots. Carbon and nitrogen contents also registered a decreased of 8.83 and $8.39 \%$ respectively when PL was used to produce maggots. However, with phosphorus and potassium contents, an increase of 49.12 and $34.21 \%$ were noted, respectively. It was concluded that small poultry farmers with 30 to 100 adult chickens, could produce the equivalence of 100 to $300 \mathrm{~kg}$ of fertilizer (NPK (15-15-15)) in semi-confinement condition.
\end{abstract}

(C) 2020 International Formulae Group. All rights reserved.

Keywords: local poultry, litter, organics substrates, maggot production, fertilizer, small farm.

\section{INTRODUCTION}

The use of organic substrates for the restoration of soil production capacity has been demonstrated by many researchers (Habimana et al., 2014; Koulibaly et al., 2015; Olaiya et al., 2015; Gomgnimbou et al., 2019; Traoré et al., 2019; Tshala Upite et al., 2019). Blanchard et al. (2014) showed that there was a diversity of organic substrates that are produced and used by the farmers in rural area. Despite this diversity, the quantities need for farm activities remain low. According to Vall et al. (2011), the organic manure needs per farm are between 7 and $28 \%$, depending on the level of integration between crop and livestock production in western Burkina Faso.

The investigations of Coulibaly et al. (2018) showed that poultry farming is an activity that can contribute to farm organic manure production from 26.46 to $35.72 \%$ in 
western Burkina Faso. The work of Ouédraogo et al. (2015) showed that despite the socio-economic and nutritional importance of local chickens, they are raised mostly in scavenging system. However, this rearing system does not promote the collection of these birds manure. The increasing of the flock size (more than 100 birds) associated with improving nutrition through the introduction of maggots and termites in birds feeding for intense could contribute to reduce scavenging of chickens in rural areas (Coulibaly et al., 2018). Ruminants stomach content, poultry manure and pig manure were mentioned as animal origin residues that attract flies, and therefore, are potentially suitable for fly larvae production (Bloukounon-Goubalan et al., 2017). Sanou et al. (2019) showed that poultry litter was the best substrate to produce maggots, with a production output of more than $80 \mathrm{~g}$ of maggot per $4 \mathrm{~kg}$ of poultry litter (dry matter basis). The maggots consume the organic substrates and reduce its quantity and quality during their development inside the substrate.

This paper, which focuses on the aspect of poultry manure production and collection, (i) assesses the amount of organic substrates that can be generated by poultry activity, (ii) gives the chemical qualities of these organic substrates and (iii) estimates the amounts of nutrients that can be provided by these organic substrates according to the type of poultry farmers.

\section{MATERIALS AND METHODS}

\section{Study site}

The study was conducted at the experimental station of the Institute of Rural Development (IDR) of Nazi Boni University (UNB). The UNB site is located on the way going to Banzon from Bobo-Dioulasso the second big city of Burkina Faso, at about 15 $\mathrm{km}$ west of Bobo-Dioulasso in the HautsBassins region, between $4^{\circ} 25^{\prime}$ west longitude and $11^{\circ} 12^{\prime}$ North latitude (Figure 1). The study site belongs to the southern Sudanese climate, whose annual rainfall is between 800 $\mathrm{mm}$ and $1200 \mathrm{~mm}$ (Fontes and Guinko, 1995).
Average rainfall for the last ten years (20062015 ) is $1065.45 \mathrm{~mm}$ with the lowest in 2011 $(775.4 \mathrm{~mm})$ and the highest in 2014 (1278.3 $\mathrm{mm})$. Rainfall in 2017 was $747.9 \mathrm{~mm}$ for 82 days.

\section{Production of poultry litter}

Fifty-four (54) local chickens (females) aged eighteen (18) months were used. These chickens were randomly divided into three batches with 18 birds per batch. Before the introduction of the chickens into the boxes, rice husks were spread on the floor as litter at $51.29 \mathrm{~kg}, 53.21 \mathrm{~kg}$ and $51.88 \mathrm{~kg}$ of dry matter (DM) for batches 1, 2 and 3 respectively.

The chickens were raised inside the boxes in semi-confinement for 6 months from January to June 2017, with six hours of scavenging per day in a yard provided, and receiving a supplementary feed composed of cracked maize and dried fish powder. An acceptability test with maggots was done during one month (February 2017). Feed supplement was given three times per day (8h00, $12 \mathrm{~h} 00$ and 15h00). Water was available add-libitum. At the end of the experiment, the quantities of poultry litter (droppings and rice husk) were weighed per batch.

\section{Production of the litter residues after maggot's production}

Containers of $0.32 \mathrm{~m}^{2}$ surface and 0.20 $\mathrm{m}$ deep each, were used for maggot production. In each container, $3.30 \mathrm{~kg}$ of the dry poultry litter was humidified with 7 litters of water and then well mixed. The containers were exposed for 24 hours in the shade to attract the flied for egg laying. The containers were then covered with bags allowing more or less air circulation inside the containers. The maggots were harvested 4 day after covering, by the method of migration using mesh sieves of $3 \mathrm{~mm}$ and with the benefit of the light allergic property of the maggots. The production was done in 3 steps to allow the harvesting of the whole maggots in one day. The first step was to start production with 3 containers. The second step was to use a serial 
of 3 other containers to start with the maggot production the day corresponding to the harvesting of the maggots from the first step. The third step consisted in launching a last production with 3 other containers the day of harvesting the maggots from the second step. The production of maggots was made in total with 9 metal containers.

\section{Determination of chemical parameters}

Dry matter contents of the poultry litter before and after maggot production was determined by placing $1 \mathrm{~kg}$ sample from each batch in an oven at $105^{\circ} \mathrm{C}$ for 72 hours.

Total carbon $(\mathrm{C})$, total nitrogen $(\mathrm{N})$, total phosphorus (P-total), total potassium (Ktotal) and $\mathrm{pH}_{\mathrm{H} 2 \mathrm{O}}$, of poultry litter (PL) and residues of maggots' production (RMP) were determined. The analyses were done at the laboratory of the Department of Gestion des Ressources Naturelles et Système de Production (GRN-SP) of INERA Farako-Ba (Bobo-Dioulasso). Soil $\mathrm{pH}_{\mathrm{H} 2 \mathrm{O}}$ was determined according to the ratio 1/2.5 through a suspension of organic substrate sample in the distilled water (AFNOR, 1981). Total C was determined by Walkley and Black (1934) procedure. Total $\mathrm{N}$ and total $\mathrm{P}$ were determined by KJELDAHL digestion method (Hillebrand et al., 1953). Total K was dosed using flame photometer after mineralisation of organic substrate samples.

\section{Estimation of the quantities of the poultry litter before and after maggots production according to farm type}

The typology performed by Coulibaly et al. (2018) in western Burkina Faso was used. Ended, this author used 5 types of poultry farms to estimate litter production: Type 1 (109 chickens), Type 2 (30 chickens), Type 3 (43 chickens), Type 4 (55 chickens) and Type 5 (115 chickens). The quantity (Q) of poultry litter (PL) or the residues after maggots production (RMP) was calculated for a year according to the following formula:
$\mathrm{Q}(\mathrm{kg})=\frac{N b^{*} q}{18} * 2$ (with $N b=$ number of poultries per type of farms, $q=$ the quantity of PL or RMP gotten with 18 poultries during 6 months of experiment, $2=$ the number of $P L$ or RMP production per year, the duration of a production being 6 months).

Estimation of $\mathrm{N}, \mathrm{P}_{2} \mathrm{O}_{5}$ and $\mathrm{K}_{2} \mathrm{O}$ quantities of the poultry litter before and after maggots production according to farm type.

The amount of nitrogen $\left(\mathrm{Q}_{\mathrm{N}}\right)$ was estimated as follows:

QN $(\mathbf{k g})=N(\%) * Q$, with $N(\%)=N$ content in the PL or RMP and $Q=$ quantity of $P L$ or RMP estimated per type of farms.

The amount of phosphorus pentoxyde $\left(\mathrm{Q}_{\text {P205 }}\right)$ was estimated as follows :

Qp205 $(\mathbf{k g})=Q *\left(P * \frac{M \mathrm{P} 2 \mathrm{O} 5}{M P}\right)$, with $Q=$ quantity of $P L$ or RMP estimated per type of farms, $P=$ phosphorus content in the $P L$ or $R M P, M P 2 O 5=$ molar mass of phosphorus pentoxyde and $M P=$ molar mass of phosphorus.

The amount of potassium oxide $\left(\mathrm{Q}_{\mathrm{K} 2 \mathrm{O}}\right)$ was estimated as follows:

$\mathbf{Q}_{\text {к20 }}(\mathbf{k g})=Q *\left(K * \frac{M K 2 O}{M K}\right)$, with $Q=$ quantity of PL or RMP estimated per type of farms, $K=$ potassium content in the $P L$ or $R M P, M K 2 O=$ molar mass of potassium oxide and $M K=$ molar mass of potassium.

\section{Data analysis}

Data were subjected to Microsoft Excel software, version 2010, for means calculations and tables generation. Xlstat software 2018.5 version was used to perform analysis of variance (ANOVA), and means separation was done at $5 \%$ confidence interval using the Newman-Keuls test. 


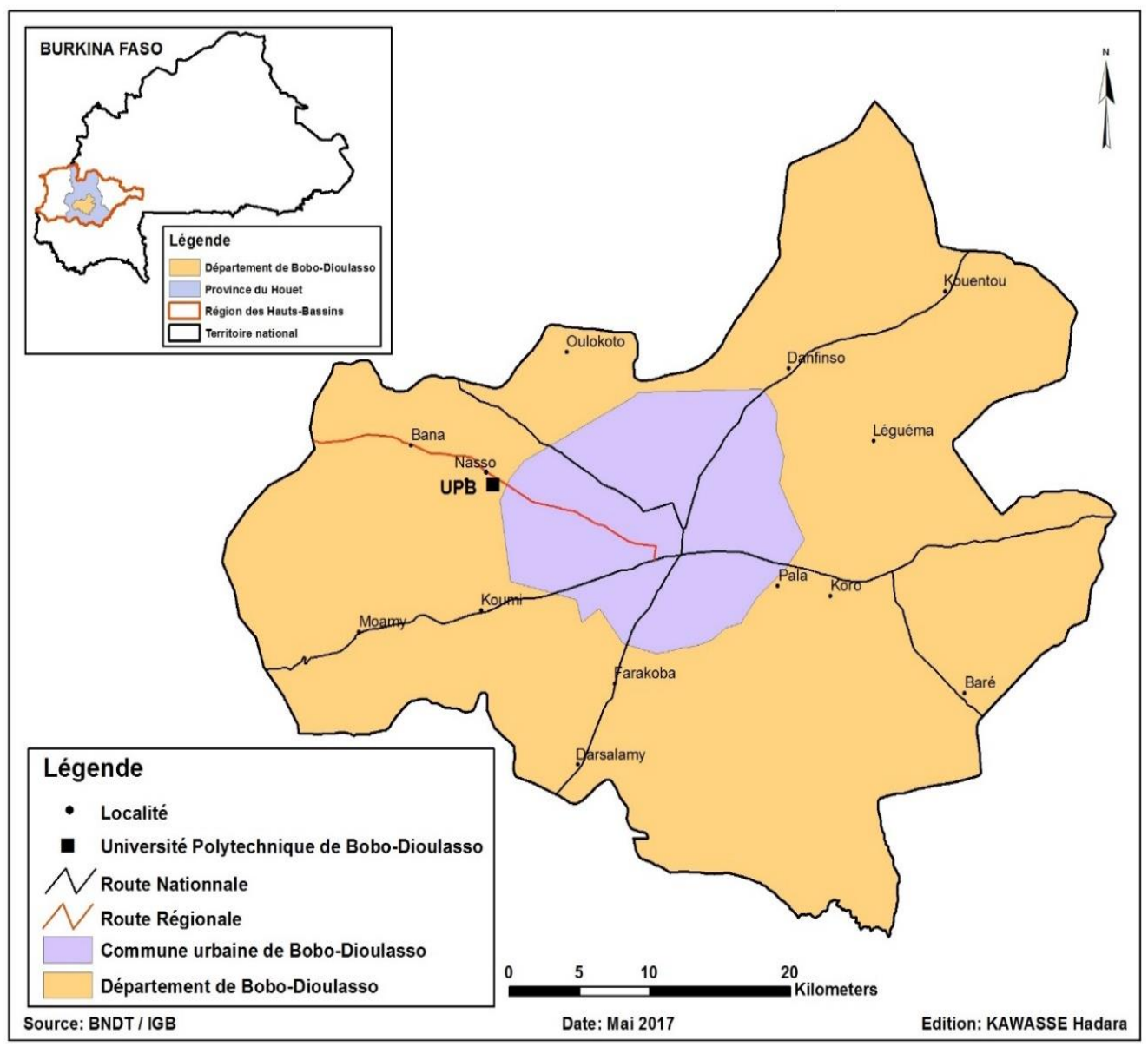

Figure 1 : Localisation of the site.

\section{RESULTS}

\section{Evaluation of the poultry litter quantity}

Table 1 gives the quantities of the poultry litter (PL) produced. The quantity of the PL produced by 18 birds after 6 months varied between 218.89 and $237.83 \mathrm{~kg}$. The means quantity was $226.06 \pm 7.84 \mathrm{~kg}$ (with $12.56 \mathrm{~kg} /$ chicken).

\section{Dry matter and chemical characteristics of the substrates before and after maggot's production}

The chemical characteristics of the poultry litter (PL) and the residues after maggots' production (RMP) are shown in
. The data show a decrease in PL weight of $30.33 \%$ after maggots' production. There is also a decrease in total nitrogen and organic carbon contents of the RMP compared to the PL. On the other hand, the residues after maggot production were higher in phosphorus and potassium contents and $\mathrm{pH}$ than the LV. The mineral matter in the RMP (24.685 \pm $1.26 \%$ ) was also significantly higher compared to the PL $(17.425 \pm 0.57 \%)$. The Analysis of variance showed significant differences $(p<0.05)$ between the PL and the RMP for the different parameters, except the $\mathrm{C} / \mathrm{N}$ ratio.

\section{Assessment of organic substrates produced} by the different types of poultry farmers

The results of the estimate gave 2888 and $2006 \mathrm{~kg}$ for the poultry litter (PL) and the 
residues after maggots production (RMP), respectively for poultry farmers (Type 5) with higher number of chickens (Table 3). Poultry farmers with lower number of chickens (Type 2), produced less than 1 tonne of PL and RMP.

Estimation of the possible quantities of $\mathbf{N}$, $\mathrm{P}_{2} \mathrm{O}_{5}$ et $\mathrm{K}_{2} \mathrm{O}$ in the PL and the RMP according to farmers type

Table 4 shows that type 5 farmers with 115 chickens would produce $79.12 \mathrm{~kg}$ of $\mathrm{N}$, $71.04 \mathrm{~kg}$ of $\mathrm{P}_{2} \mathrm{O}_{5}$ and $49 \mathrm{~kg}$ of $\mathrm{K}_{2} \mathrm{O}$ with crude poultry litter. Type 2 poultry farmers with small number of poultries (30 chickens) would produce only $20.85 \mathrm{~kg}$ of N, $18.72 \mathrm{~kg}$ of $\mathrm{P}_{2} \mathrm{O}_{5}$ and $12.91 \mathrm{~kg}$ of $\mathrm{K}_{2} \mathrm{O}$.

After maggot production, it was observed that the amount of $\mathrm{N}, \mathrm{P}_{2} \mathrm{O}_{5}$ and $\mathrm{K}_{2} \mathrm{O}$ could increase with the number of chickens (Table 5). However, the amount of $\mathrm{N}_{\text {and }} \mathrm{K}_{2} \mathrm{O}$ could decrease after the poultry litter being used for maggot production. Conversely, the amount of $\mathrm{P}_{2} \mathrm{O}_{5}$ could increase from 1 to $2 \mathrm{~kg}$ after maggot production.

Table 1 : Quantity of poultry litter produced.

\begin{tabular}{lc}
\hline Poultry batch & $\begin{array}{c}\text { *Poultry litter } \\
\text { (kg de DM) }\end{array}$ \\
\hline Lot $1(\mathrm{n}=18)$ & 218.89 \\
Lot $2(\mathrm{n}=18)$ & 237.83 \\
Lot $3(\mathrm{n}=18)$ & 221.47 \\
Average \pm SD & $226.06 \pm 7.84$
\end{tabular}

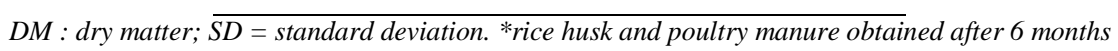

Table 2: Dry matter and chemical characteristics of poultry litter (PL) and residues of maggots' production (RMP).

\begin{tabular}{|c|c|c|c|c|c|c|c|c|}
\hline & $\begin{array}{l}\text { DM } \\
(\mathrm{kg})\end{array}$ & $\begin{array}{l}\text { MM } \\
(\%)\end{array}$ & $\mathrm{pH}_{\mathrm{H} 2 \mathrm{O}}$ & $\begin{array}{c}\mathrm{C} \\
(\%)\end{array}$ & $\begin{array}{c}\mathrm{N} \\
(\%)\end{array}$ & $\mathbf{C} / \mathbf{N}$ & $\begin{array}{l}\text { P-total } \\
(\mathrm{mg} / \mathrm{kg})\end{array}$ & $\begin{array}{l}\text { K-total } \\
(\mathrm{mg} / \mathrm{kg})\end{array}$ \\
\hline PL & $3.33^{\mathrm{a}} \pm 0.10$ & $17.43^{\mathrm{b}} \pm 0.57$ & $7.43^{\mathrm{b}} \pm 0.07$ & $47.90^{\mathrm{a}} \pm 0.33$ & $2.74^{\mathrm{a}} \pm 0.10$ & $17.51 \pm 0.70$ & $10741.41^{\mathrm{b}} \pm 3735.66$ & $14078.52^{\mathrm{b}} \pm 363.62$ \\
\hline RMP & $2.32^{\mathrm{b}} \pm 0.19$ & $24.69^{\mathrm{a}} \pm 1.26$ & $7.57^{\mathrm{a}} \pm 0.17$ & $43.67^{b} \pm 0.73$ & $2.51^{\mathrm{b}} \pm 0.22$ & $17.52 \pm 1.59$ & $16017.58^{\mathrm{a}} \pm 1199.95$ & $18894.38^{\mathrm{a}} \pm 899.21$ \\
\hline $\mathbf{F}$ & 100.81 & 246.475 & 5.006 & 246.475 & 8.230 & 0.001 & 16.274 & 221.869 \\
\hline $\operatorname{Pr}>\mathrm{F}$ & $<0.0001$ & $<0.0001$ & 0.04 & $<0.0001$ & 0.011 & 0.979 & 0.001 & $<0.0001$ \\
\hline Significant & Yes & Yes & Yes & Yes & Yes & No & Yes & Yes \\
\hline
\end{tabular}

$D M=$ dry matter $; M M=$ mineral matter $P L=$ poultry litter $; R M P=$ residues of maggots ' production $; C=$ carbon; $N$ : nitrogen ; P-total : total phosphorus ; K-total : total potassium. 
Table 3 : Estimation of organic substrates quantities produced per type of poultry farmers.

\begin{tabular}{cccccc}
\hline Types of poultry farmers & Type $\mathbf{1}$ & Type 2 & Type 3 & Type 4 & Type 5 \\
\hline $\begin{array}{c}\text { Nb of poultries } \\
\text { (Coulibaly et al., 2018) }\end{array}$ & 109 & 30 & 43 & 55 & 115 \\
PL (kg) & 2728 & 761 & 1068 & 1389 & 2888 \\
RMP (kg) & 1895 & 529 & 742 & 965 & 2006 \\
\hline
\end{tabular}

$\mathrm{Nb}=$ number $; \mathrm{PL}=$ poultry litter; $R M P=$ residues of maggots ' production

Table 4 : Estimation of quantity of $\mathrm{N}_{2} \mathrm{P}_{2} \mathrm{O}_{5}$ et $\mathrm{K}_{2} \mathrm{O}$ that could be brought by PL per type of poultry farmers.

\begin{tabular}{|c|c|c|c|c|c|}
\hline Types of poultry farmers & Type 1 & Type 2 & Type 3 & Type 4 & Type 5 \\
\hline $\mathrm{N}(\mathrm{kg})$ & 74.74 & 20.85 & 29.27 & 38.07 & 79.12 \\
\hline $\mathrm{P}_{2} \mathrm{O}_{5}(\mathrm{~kg})$ & 67.11 & 18.72 & 26.28 & 34.18 & 71.04 \\
\hline $\mathrm{K}_{2} \mathrm{O}(\mathrm{kg})$ & 46.29 & 12.91 & 18.12 & 23.57 & 49.00 \\
\hline
\end{tabular}

Table 5: Estimation of quantity of $\mathrm{N}, \mathrm{P}_{2} \mathrm{O}_{5}$ et $\mathrm{K}_{2} \mathrm{O}$ that could be brought by RMP per type of poultry farmers.

\begin{tabular}{cccccc}
\hline Types of poultry farmers & Type $\mathbf{1}$ & Type 2 & Type 3 & Type 4 & Type 5 \\
\hline $\mathrm{N}(\mathrm{kg})$ & 47.59 & 13.27 & 18.63 & 24.24 & 50.37 \\
$\mathrm{P}_{2} \mathrm{O}_{5}(\mathrm{~kg})$ & 69.53 & 19.39 & 27.22 & 35.41 & 73.60 \\
$\mathrm{~K}_{2} \mathrm{O}(\mathrm{kg})$ & 43.15 & 12.04 & 16.90 & 21.98 & 45.68 \\
\hline
\end{tabular}

$N=$ nitrogen, $\mathrm{P}_{2} \mathrm{O}_{5}=$ phosphorus pentoxyde, $\mathrm{K}_{2} \mathrm{O}=$ potassium oxide

\section{DISCUSSION}

The mean quantity of the poultry litter (PL) produced in 6 months was $12.56 \mathrm{~kg}$ per bird. Therefore, the estimated annual production is $25.12 \mathrm{~kg} / \mathrm{bird}$. According to the data found by Coulibaly et al. (2018), this estimated quantity is $81.40 \%, 79.77 \%$ and $23.5 \%$ higher than the quantities produced in rural areas, respectively for extensive system (4.67 kg / bird / year), semi-intensive system (5.08 kg / bird / year) and confinement system (19.21 kg / bird / year). The contribution of the rice husk as litter could explain this important variation of the organic substrates (OS) produced in the current experiment. Feed supplement type as well as the method of feeding could also explain this production of OS. The results also show that the quantity of the PL decreased by $30.33 \%$ after maggots production, and the same situation was seen with the PL carbon and nitrogen contents which decreased from 8.83 and $8.39 \%$, respectively, after maggot production. Similar results were also obtained with different 
substrates including poultry manure by other authors (Zhu et al., 2012, BloukounonGoubalan et al., 2017). The decrease in the PL weight, and the carbon and nitrogen contents could be explained by the decomposition of the molecular carbon chains compounds by the maggots and the other micro-organisms according to Recou et al. (2017) who reported that in the presence of decomposed carbon, micro-organisms assimilate the available nitrogen during decomposition and contribute to the storage of organic matter by humification. Newton et al. (2005) who observed similar results, related this to the conversion (by the larvaes into their biomass) of the residual proteins and other nutrients from the organic substrates.

Mineral matter, $\mathrm{pH}$, total phosphorus and total potassium levels were higher in the RMP compared to their values in the PL used for maggot production. Bloukounon-Goubalan et al. (2017) justify the increasing of the $\mathrm{pH}$ through ammonia production during the ammonification and mineralization of organic nitrogen following the maggots' activities. The present results on phosphorus $(\mathrm{P})$ and potassium $(\mathrm{K})$ are discordant with the results of Newton et al. (2005) who obtained $44.1 \%$ and $55.8 \%$, respectively for $\mathrm{P}$ and $\mathrm{K}$ with pig manure used to produce larvae of Hermetia illucens (black soldier fly). The present results could be explained by the nature of the larvae that are derived from Musca domestica and Calliphora vomitoria. It can also be hypothesized that the nature of the organic substrate used could influence the utilization of the nutrients by the larvaes. The interaction between maggots and other micro-organisms might also be a hypothesis to justify the richness of the residues in $\mathrm{P}$ and total $\mathrm{K}$.

The simulation results showed that poultry farmers can produce from 761 to 2888 $\mathrm{kg}$ of poultry litter annually with 30 and 115 birds respectively. When the poultry litter is used for maggot production, this would give 529 to $2006 \mathrm{~kg}$ of residues after maggots' production for 30 and 115 birds respectively. According to the works of Coulibaly et al. (2018), these quantities of organic substrates are higher than the substrates produced by the same poultry farmers (between 196 and 800 $\mathrm{kg}$ ) with the same number of birds. The use of organic substrates derived from the poultry activity in soil fertilization that was pointed out already by several authors (Agbede et al., 2013; Zhu et al., 2015; Habib et al., 2015; Adekiya et al. 2016). In addition, the results of this study show that these organic substrates can bring significant quantities of $\mathrm{N}, \mathrm{P}_{2} \mathrm{O}_{5}$ and $\mathrm{K}_{2} \mathrm{O}$ for the farmers. Therefore, poultry household with 30 bird could produce the equivalence of $100 \mathrm{~kg}$ of NPK (15-15-15). For poultry farmers with 100 birds, these could produce the equivalence of $300 \mathrm{~kg}$ of NPK (15-15-15).

\section{Conclusion}

The study shows that poultry rearing in semi-confinement with the use of rice husk as litter can allow poultry farmers to increase their organic matter production by over $70 \%$ compared to their current practice. The chemical quality of the organic matter showed that small poultry farmers can produce the equivalence of 100 to $300 \mathrm{~kg}$ of the complex NPK (15-15-15). The organization of poultry farming around these issues can be an important additional source of organic manure production that can contribute to sustainable management of soil fertility.

\section{COMPETING INTERESTS}

The authors declare that there is no conflict of interest with other research.

\section{AUTHORS' CONTRIBUTIONS:}

KC, FS, SP, JPN, MBS conceived the study. $\mathrm{KC}$ and MBS conducted and analyzed the experiments shown in the text. KC prepared the first draft. All authors reviewed the results and approved the final version of the manuscript.

\section{ACKNOWLEDGEMENTS:}

The authors would like to thank the Suisse Programme for Research on Global Issues for Development, which funded the 
IFWA project (Insect As Feed in West Africa).

\section{REFERENCES}

Adekiya AO, Agbede TM, Stephen OO. 2016. The effect of three years of tillage and poultry manure application on soil and plant nutrient composition, growth and yield of cocoyam. Expl. Agric., 52(3): 466-476.

DOI:10.1017/S0014479715000253

Association Française de Normalisation (AFNOR), 1981. Détermination du pH. In Qualité des Sols, AFNOR, NF ISO 103 90: Paris, France; 339-348.

Agbede TM, Adekiya AO, Ogeh JS. 2013. Effects of organic fertilizers on yam productivity and some soil properties of a nutrient-depleted tropical Alfisol. Archives of Agronomy and Soil Science, 59(6): 803-822. DOI: https://doi.org/10.1080/03650340.2012.6 83423

Blanchard M, Coulibaly K, Bognini S, Dugué P, Vall E. 2014. Diversité de la qualité des fumures organiques produites par les paysans d'Afrique de l'Ouest: quelles conséquences sur les recommandations de fumure? Biotechnol. Agron. Soc. Environ, $\quad$ 18(4): 512-523. https://popups.uliege.be:443/17804507/index.php?id=11654

Bloukounon-Goubalan AY, Saïdou A, Clottey V, Chrysostome CAAM, Kenis M, Mensah GA. 2017. Typology of organic residues attracting flies and their utilization in the agricultural sector in southern Benin. Int. J. Biol. Chem. Sci., 11(6): 2560-2572. DOI: https://dx.doi.org/10.4314/ijbcs.v11i6.1

Bloukounon-Goubalan AY, Saïdou A, Togbé E, Chabi F, Babatoundé S, Chrysostome CAAM, Kenis M, Mensah GA. 2017. Physical and Chemical Properties of Animals' Organic Residues Decomposed by Musca domestica and Calliphora vomitoria Larvae. Jour. Agri. Envi. Sci., 6(1): 92-104. DOI: 10.15640/jaes.v 6n1a10
Coulibaly K, Sankara F., Pousga S, Nacoulma PJ, Nacro HB. 2018. Pratiques avicoles et gestion de la fertilité des sols dans les exploitations agricoles de l'Ouest du Burkina Faso. J. Appl. Biosci., 127: 12770-12784.

DOI : https://dx.doi.org/10.4314/jab.v127i1.2

Fontes J, Guinko S. 1995. Carte de la végétation et de l'occupation du sol du Burkina Faso. In Notice Explicative. Ministère de la Coopération Française : Toulouse, France ; 67.

Gomgnimbou APK, Bandaogo AA, Coulibaly K, Sanon A, Ouattara S, Nacro HB. 2019. Effets à court terme de l'application des fientes de volaille sur le rendement du maïs (Zea mays L.) et les caractéristiques chimiques d'un sol ferralitique dans la zone sudsoudanienne du Burkina Faso. Int. J. Biol. Chem. Sci., 13(4): 2041-2052. DOI: https://dx.doi.org/10.4314/ijbcs.v13i4.11

Habib MA, Khatun R, Hossen MS. 2015. Impact of organic wastes on soil environment and yield of $\mathrm{T}$-aman rice. Progressive Agriculture, 26: 122-128. DOI: https://doi.org/10.3329/pa.v26i2.25966

Habimana S, Uwamahoro C, Uwizerwa JB. 2014. Influence of chicken manure and NPK (17-17-17) fertilizer on growth and yield of carrot. Net J Agric Sci, 2(4): 117-123.

http://www.netjournals.org/pdf/NJAS/20 14/4/14-041.pdf

Hillebrand WF, Lundell GEF, Bright HA, Hoffman JI. 1953. Applied inorganic analysis, $2^{\text {nd }}$ ed. JOHN WILEY and SONS, INC., New York, USA.

Koulibaly B, Dakuo D, Ouattara A, Traoré O, Lompo F, Zombré PN, Yao-Kouamé A. 2015. Effets de l'association du compost et de la fumure minérale sur la productivité d'un système de culture à base de cotonnier et de maïs au Burkina Faso. Tropicultura, 33(2): 125-134. http://www.tropicultura.org/index/author /koulibaly-b.html 
Newton GL, Sheppard DC, Watson DW, Burtle GJ, Dove CR. 2005. Using the black soldier fly, Hermetiaillucens, as a value-added tool for the management of swine manure. Report for Mike Williams, pp: 18.

Olaiya AO, Atayese MO, Okeleye KA, Arowolo TO, Oluwole SO. 2015. Impact of poultry manure on fruit yield and yield components of inland valley okra (Albelmoschus esculentus L.) in a forest - Savannah transition ecology of Nigeria. Net J Agric Sci, 3(4): 93-98. http://www.netjournals.org/z_NJAS_15_ 030.html

Ouédraogo B, Gnanda IB, Sanfo R, Zoundi SJ, Bayala B. 2015. Etude comparative des performances réalisées avec l'incorporation de la farine de coproduits de volaille et la farine des asticots dans des rations de poulets de chair au Burkina Faso. Rev. Ivoir. Sci. Technol., 25: 148-161. DOI : https://revist.net/REVIST_25/REVIST_2 5_11.pdf

Recous S, Lashermes G, Bertrand I. 2017. Couplages et contrôles des cycles du carbone et de l'azote par les communautés microbiennes dans les sols cultivés. Les sols et la vie souterraine: Des enjeux majeurs en agroécologie, Editions Quae, 328 p., Synthèses (Quae), 978-2-7592-2651-1. <hal-01543489>

Sanou AG, Sankara F, Pousga S, Coulibaly K, Nacoulma JP, Ouédraogo I, Nacro S, Kenis M, Sanon A, Somda I. 2018. Production de masse de larves de Musca domestica L. (Diptera : Muscidae) pour l'aviculture au Burkina Faso : Analyse des facteurs déterminants en oviposition naturelle. J. Appl. Biosci., 134: 13689 13701.

DOI: https://dx.doi.org/10.4314/jab.v134i1.6

Tshala Upite J, Kitabala Misonga A, Kasongo Mukonzo lenge E, Nyembo Kimuni L. 2019. Effets des composts ménagers sur les propriétés du sol et sur la productivité des cultures légumières : cas de la tomate (Lycopersicon esculentum Mill). Int. J. Biol. Chem. Sci., 13(7): 3411-3428. DOI: https://dx.doi.org/10.4314/ijbcs.v13i7.35

Traoré A, Yameogo PL, Nambon DIA, Traoré K, Bazongo P, Traoré O. 2019. Utilisation du tourteau de neem (Azadirachta indica) et de la micro-dose d'engrais minéraux pour la production $\mathrm{du}$ maïs en zone Sud-soudanienne du Burkina Faso. Int. J. Biol. Chem. Sci., 13(6): 2618-2626. DOI: https://dx.doi.org/10.4314/ijbcs.v13i6.15

Vall E, Koutou M, Blanchard M, Coulibaly K, Diallo MA, Andrieu N. 2012. Intégration agriculture-élevage et intensification écologique dans les systèmes agro-sylvopastoraux de l'Ouest du Burkina Faso, province du Tuy. In Partenariat, Modélisation, Expérimentations : Quelles Leçons pour la Conception de l'Innovation et l'Intensification Ecologique? Vall E, Andrieu N, Chia, Nacro HB (Eds), Cirad, $1^{\text {st }}$ ed Colloques, Bobo-Dioulasso, Burkina Faso <hal00718613>: 13p.

Walkley A, Black IA. 1934. An examination method of the detjareff and a proposed modification of the chromic acid titration method. Soil Science, 37: 29-38. DOI: 10.1097/00010694-193401000-00003

Zhu F, Wang W, Hong C, Feng M, Xue Z, Chen X, Yao Y, Yu M. 2012. Rapid production of maggots as feed supplement and organic fertilizer by the two-stage composting of pig manure. Bioresour Technol., 116: 485-491. DOI: 10.1016/j.biortech.2012.04.008

Zhu F, Yao Y, Wang S, Du R, Wang, W, Chen X, Hong C, Qi B, Xue Z, Yang H. 2015. Housefly maggot treated composting as sustainable option for pig manure management. Waste Manag., 35: 62-67. DOI : 10.1016/j.wasman.2014.10.005. 